Innlegg på inntil 400 ord lastes opp i http://mc.manuscriptcentral.com/tidsskriftet.

Redaksjonen forbeholder seg retten til å foreta redaksjonelle endringer.

Forfattere av vitenskapelige artikler har automatisk tilsvarsrett (jf. Vancouver-gruppens regler).

\section{HPV-testing og livmorhalskreft}

Vi takker for interessen for vår artikkel $(1,2)$. Bjørn Hagen og Kåre Augensen (3) synes å oppfatte at vi anbefaler direkte konisering uten histologisk verifisering ved positiv HPV-mRNA-test sammen med høygradig cytologi og dersom kvinnen er eldre enn 40 år. Vi understreker at Universitetssykehuset Nord-Norge (UNN) følger de nasjonale retningslinjene slik de er nedfelt i Veileder for gynekologisk onkologi 2009, og vi er selvfølgelig også enige i at retningslinjene ikke kan endres på bakgrunn av en retrospektiv studie.

Hensikten med masseundersøkelsen mot livmorhalskreft er å identifisere kvinner med høygradige forstadier til livmorhalskreft (CIN2+) slik at disse kan få behandling før kreft utvikles. Vår studie viser at positiv HPV-mRNA-test har høy positiv prediktiv verdi for histologisk CIN2+ (2). Tall fra Kreftregisteret viser at $88,1 \%$ av kvinner med histologisk bekreftet CIN2+ får påvist CIN2+ i cervixkonus (4). Til sammenligning viser vår studie at $94,2 \%$ av kvinner med cytologisk høygradig interepitelial neoplasi (HSIL) og positiv HPV mRNA-test får påvist histologisk CIN2+ (2).

Det ser ut som om positiv prediktiv verdi (PPV) for kreft er høyere ved positiv HPVmRNA-test enn ved histologisk bekreftet CIN2 $(5,6)$. I vår studie fant vi 13 kvinner med utviklet kreft til tross for lavgradig cytologi seks måneder tidligere (2).

Som vi formulerte i vår omtale av artikkelen (1), kan resultatene indikere at kvinner med cytologisk høygradige celleforandringer og positiv HPV-mRNA-test kan behandles direkte uten forutgående biopsi. Våre tall viser at det for kvinner over 40 år som ikke planlegger flere barn, kan synes fornuftig å behandle direkte, uavhengig av resultat på cytologisk prøve. Dette er konklusjonene som ble publisert i PLoS ONE (2), og som også ble referert i Tidsskriftet (1). À påstå at dette er det samme som å anbefale behandlingsstrategier i strid med gjeldende nasjonale retningslinjer, må skyldes en misforståelse.

Det planlegges nå prospektive studier i Danmark og Tyskland for å undersøke om direkte konisering er hensiktsmessig behandling hos noen kvinner. Dersom resultatene kan bekreftes i prospektive studier, er det ikke umulig at retningslinjene i fremtiden kan bli endret fra morfologisk vurde- ring av cytologi og histologi til bruk av molekylære markører for å identifisere kvinnene med høyest risiko for kreftutvikling.

\section{Sveinung Sørbye \\ Silje Fismen \\ Tore Jarl Gutteberg \\ Elin Mortensen}

Litteratur

1. Sørbye S. HPV-mRNA-test påviser celleforandringer. Tidsskr Nor Legeforen 2010; 130: 2214.

2. Sørbye SW, Fismen S, Mortensen E et al. Triage of women with minor cervical lesions: data suggesting a «test and treat» approach for HPV E6/E7 mRNA-testing. PLoS One 2010; 5: e12724.

3. Hagen B, Augensen K. Villedende om HPV-testing. Tidsskr Nor Legeforen 2011; 131: 14

4. Kreftregisteret. Masseundersøkelsen mot livmorhalskreft - årsrapport 2008.

5. Sørbye SW, Fismen S, Mortensen E et al. HPV mRNA-test in women with minor cervical lesions: experience of the University Hospital of North Norway. J Virol Methods 2010; 169: 219-22.

6. Sørbye S. HPV, celleforandringer og kreft. Bioingeniøren 2010; 11: 6-12.

\section{UV-A-stråling og melanomer}

I nr. 18/2010 omtalte Veierød og medarbeidere sammenhengen mellom solarier og hudkreft (1). Vi har i 30 år hevdet at soling, særlig bråsoling, er hovedårsaken til hudkreft og vist det ved nord-sør-gradienter $\mathrm{i}$ insidens, kroppsfordeling osv. (2). Dette er nå allment akseptert.

For melanomer er epidemiologien mer komplisert $(2,3)$. Utearbeidende bønder og fiskere har forbausende lav risiko. Ikke-melanomer skyldes mest UV-B $(280-315 \mathrm{~nm})$, mens vi trodde at melanomer kunne forårsakes av både UV-B og UV-A (315-400 nm) (2), og at UV-A var særlig melanominduserende (3). Setlows banebrytende fiskeeksperimenter fra 1993 (som bekreftet UV-A-strålingens melanominduserende effekt) kan imidlertid være feil (4). Melanomer kan induseres $i$ transgene mus og Monodelphis domestica ved UV-B, men ikke ved UV-A $(2,5)$. Flere nyere epidemiologiske undersøkelser synes å gå i motsatt retning (6-8).

Bruk av solarier (som gir relativt mye UV-A) synes å gi økt risiko for melanom. Tidligere epidemiologiske studier, utført med sterkere solarier enn nå, viste ingen klar melanomrisiko (9). Vi får imidlertid tro at de nyere undersøkelsene er best. Nye dyreforsøk viser altså at UV-A ikke gir melanomer, mens nye epidemiologiske solariestudier antyder det motsatte $(1,6-8)$. Problemet er altså ikke løst, og vi må vente på ny forskning, som vil være av stor helsemessig betydning, siden både sol og solarier gir mye D-vitaminer (5), solen bare om sommeren. D-vitaminets mange helsevirkninger er nå lærebokstoff.

\section{Asta Juzeniene}

Oslo universitetssykehus

\section{Johan Moan}

Oslo universitetssykehus

og

Fysisk institutt

Universitetet i Oslo

Litteratur

1. Veierød MB, Nilsen LT, Robsahm TE. Solarier, vitamin D og hudkreft. Tidsskr Nor Legeforen 2010; 130: 1818-21

2. Moan J, Porojnicu AC, Dahlback A. Ultraviolet radiation and malignant melanoma. Adv Exp Med Biol 2008; 624: 104-16.

3. Moan J, Dahlback A, Setlow RB. Epidemiological support for an hypothesis for melanoma induction indicating a role for UVA radiation. Photochem Photobiol 1999: 70: 243-7.

4. Mitchell DL, Fernandez AA, Nairn RS et al. Ultraviolet $A$ does not induce melanomas in a Xiphophorus hybrid fish model. Proc Natl Acad Sci U S A 2010; 107: 9329-34.

5. Cicarma E, Porojnicu AC, Lagunova Z et al. Sun and sun beds: inducers of vitamin $D$ and skin cancer. Anticancer Res 2009; 29: 3495-500.

6. Veierød MB, Adami HO, Lund E et al. Sun and solarium exposure and melanoma risk: effects of age, pigmentary characteristics, and nevi. Cancer Epidemiol Biomarkers Prev 2010; 19: 111-20.

7. Lazovich D, Vogel RI, Berwick M et al. Indoor tanning and risk of melanoma: a case-control study in a highly exposed population. Cancer Epidemiol Biomarkers Prev 2010; 19: 1557-68.

8. Autier P, Doré JF, Eggermont AM et al. Epidemiological evidence that UVA radiation is involved in the genesis of cutaneous melanoma. Curr Opin Oncol 2010; doi: 10.1097/CC0.0b013e3283436e5d.

9. International Agency for Research on Cancer. The association of use of sunbeds with cutaneous malignant melanoma and other skin cancers: A systematic review. Int J Cancer 2007; 120: $1116-22$

\section{M.B. Veierød}

og medarbeidere svarer:

Takk for interessen for oversiktsartikkelen (1). Sammenfallende resultater fra ulike undersøkelser er avgjørende når råd til befolkningen utformes.

Som Juzeniene \& Moan skriver, finnes det ikke fullgode dyremodeller for induksjon av malignt melanom, og dyrestudiene gir motstridende resultater om effekten av UV-B- og UV-A-stråling.

Solarier gir begge typer stråling (1). 
Randomiserte, kontrollerte studier av solarier og risiko for melanom krever lang forsøkstid med mange forsøkspersoner og er uaktuelt av etiske grunner. Råd baseres på epidemiologiske studier, med den usikkerheten det innebærer. Økologiske studier av geografisk variasjon i kreftforekomst/ dødelighet er billige, har store kontraster i eksponering og mer stabil eksponering enn individbaserte studier. Siden eksponering og sykdomsforekomst/dødelighet måles på gruppenivå, vet vi ikke om det er de eksponerte som får sykdommen/dør og kan ikke kontrollere for konfundering på individnivå. Økologiske studier er hypotesegenererende og kausale sammenhenger kan ikke konkluderes. Resultatene av individbaserte kohort- og pasient-kontrollstudier er derfor viktige.

Nye kohort- og pasient-kontroll-studier av solariebruk og melanomrisiko (2-4) støtter det internasjonale kreftforskningssenterets klassifisering av solariebruk som karsinogen i 2009 (1). Moderne solarier avgir en større andel UV-A-stråling (1-4). Både bruk av solarier med mye UV-B-stråling og solarier med mye UV-A-stråling har økt melanomrisikoen i epidemiologiske studier (2-4). Restriktiv holdning til solarier bør opprettholdes.

Solen og kosten er våre viktigste vitamin D-kilder. I en ny og omfattende ekspertrapport (november 2010) initiert av amerikanske og kanadiske myndigheter, ble det ikke funnet kunnskapsgrunnlag for andre helsevirkninger av vitamin D enn for beinhelse (5). Ekspertene fant ikke grunnlag for å endre vitamin D-anbefalingene til den nordamerikanske befolkningen.

\section{Marit B. Veierød}

Avdeling for biostatistikk

Universitetet i Oslo

Lill Tove N. Nilsen

Statens strålevern

Trude Eid Robsahm

Kreftregisteret

Litteratur

1. Veierød MB, Nilsen LTN, Robsahm TE. Solarier, vitamin D og hudkreft. Tidsskr Nor Legeforen 2010; 130: 1818-21.

2. Veierød MB, Adami HO, Lund E et al. Sun and solarium exposure and melanoma risk: the effects of age, pigmentary characteristics and nevi. Cancer Epidemiol Biomarkers Prev 2010; 19: 111-20.

3. Lazovitch DA, Vogel RI, Berwick M et al. Indoor tanning and risk of melanoma: a case-control study in a highly exposed population. Cancer Epidemiol Biomarkers Prev 2010; 19: 1557-68.

4. Cust AE, Armstrong BK, Goumas $C$ et al. Sunbed use during adolescence and early adulthood is associated with increased risk of early onset melanoma. Int J Cancer 2010; e-publisert 28.7.2010.

5. Dietary reference intakes for calcium and vitamin D. Washington: Institute of Medicine, 2010. http:// books.nap.edu/openbook. php? record_id $=13050$ (15.1.2011).

\section{Brennemerking som terapi}

Amal Adens artikkel i Tidsskriftet nr. 23/2010 (1) fikk frem et snart 45 år gammelt minne i meg. Hun beskriver at det i Somalia ikke er uvanlig «å brenne med oppvarmet metall forskjellige steder på kroppen, for eksempel ved mistanke om lungebetennelse».

Like etter Seksdagerskrigen i 1967 ble jeg som norsk pediater sammen med to sykepleiere sendt ned til palestinske flyktningleire for å ta oss av barna som ofte var i en sørgelig forfatning. 10 000-20000 mennesker bodde i tilfeldige telt rett på sandbakken. Det var lite vann og ikke organiserte hygieniske tiltak. Som oftest gjorde flyktningene sitt fornødne rett på bakken. Deretter ble det virvlet opp i sandstormene, som innfant seg i korte perioder til samme tid daglig, noe som forårsaket luftveisinfeksjoner og diaré. En sliten britisk lege som hadde arbeidet der, pakket og forsvant straks vi kom. Jeg rakk å spørre om de viktigste diagnosene, og ganske kort svarte hun: «brennemerker på brystet er pneumoni, brennemerker på magen er diaré.»

Så ille var det nok ikke, men noen slike så vi hver uke. Vi norske ble veldig fortvilte og opprørte over denne formen for terapi. Merkene var oftest små og runde og ga mistanke om at de var laget med sigaretter.

Så en dag kom det en mamma med et hostende barn som hadde helt ferske brennemerker flere steder på brystet. Jeg laget et lite skuespill, førte pekefingeren opp og ned, og med en høy, langsom stemme ba jeg tolken fortelle moren og de seks-sju andre som ventet i teltet, at dette måtte de ikke giøre; det var vondt og uten effekt. Moren så oppmerksomt på meg, og da tolken var ferdig med sitt, dro hun raskt ned kjolelinningen og viste meg ferske brennemerker på sitt eget bryst: «Jeg hostet også og ble bra etter at jeg ble brent!».

I det samme hørte jeg et av de høye hyl fra det lille teltet der sykepleierne satte en av de mange penicillinsprøytene for pneumoni den dagen. Da skjønte jeg at for barna var den ene terapien kanskje like vond som den andre, og at begge var gitt med omsorg og gode hensikter. Det var en erkjennelse som fullstendig tok bort den fordømmelsen jeg hadde kjent, og som var et dårlig utgangspunkt for det vennskapet som etter hvert utviklet seg mellom det norske teamet og pasientene. Det ble mindre og mindre brennemerker i løpet av de månedene jeg var der. Og da jeg ett år senere arbeidet på samme sted, så jeg ingen.

Senere har jeg lest meg til at brenning som terapi, var vanlig i Europa opp mot 1870-årene. Det ble brukt av den ene parten i den fransk-tyske krigen, og motpartens fanger som ble behandlet på denne måten, trodde at det var et ledd $\mathrm{i}$ tortur.

\footnotetext{
Helene Pande

Oslo

Litteratur

1. Aden A. Helse og minoriteter. Tidsskr Nor Legeforen 2010; 130: 2436.
} 